\title{
Microfinance Banks, Small and Medium Scale Enterprises and COVID-19 Pandemic in Nigeria
}

\author{
Bako Yusuf Adebola \\ The Federal Polytechnic, Ilaro, Nigeria \\ Oyegoke Adebusola Adebola, \\ Yaba College of Technology \\ Idowu Afolasade Florence, \\ Gateway ICT Polytechnic Saapade, Nigeria \\ Aderemi Timothy Ayomitunde \\ Bells University of Technology, Ota, Nigeria
}

Doi:10.19044/elp.v8no2a1 URL:http://dx.doi.org/10.19044/elp.v8no2a1

Submitted: 11 February 2021

Copyright 2021 Author(s)

Accepted: 20 April 2021

Under Creative Commons BY-NC-ND

Published: 30 June 2021

4.0 OPEN ACCESS

\begin{abstract}
Corona virus otherwise known as COVID-19 has left indelible marks on both human beings and businesses globally. When the virus emerged in Wuhan, China in late 2019, it was viewed as China`s problem. Nobody ever envisioned that the novel virus could spread and result into global pandemic within few months. Meanwhile, the aftermath effects of COVID-19 on various socioeconomic activities might not be different from global financial crisis of 2008, which left no economy unaffected. Against this backdrop this study was carried out with a view to investigating the impact of microfinance credit on entrepreneurship development amidst COVID-19 pandemic using some selected small and medium enterprises engaging in essentials such as food and consumables, oil and gas and pharmaceuticals in Sango-Ota industrial estate of Ogun state, Nigeria. Primary data were collected with the aid of well-structured set of questionnaire from 100 SMEs which was done purposively. After subjecting the collected data to a rigorous analysis, it was discovered that over $90 \%$ of enterprises under investigation used microfinance credit for their businesses during COVID-19 pandemic. Similarly, the study submitted that micro credit increased the stock of goods of the selected and at same time orchestrated a moderate rise in profit for the majority of the SMEs selected for the survey. Consequently, the important findings that originated from this study brought the following recommendations for the policy makers, financial institution and all the stakeholders engaging in SMEs in Nigeria that credit from micro finance has the capacity to facilitate the development of entrepreneurship through expansion of outputs and profitability of SMEs in Nigeria. And as such, the policymakers in Nigeria should create an enabling environment that will facilitate microfinance institution to provide better credit and other
\end{abstract}


financial facilities to SMEs in the country.

Keywords; Microfinance Bank, SMEs, COVID-19, Pandemic and Nigeria JEL Classification: M20; M21

\section{Introduction}

The impact of small and medium scale enterprises on national development in Nigeria cannot be undermined (Okoh, 2020; Aderemi et al., 2019; Tehseen \& Ramayah, 2015). In terms of job opportunities, SMEs engaged over $70 \%$ of the Nigerian working population (NBS, 2015). In view of the above, both the public and the private sectors in Nigeria need to be involved in the development of entrepreneurial activities in the country. This is because SMEs are the foundation of industrial revolution in any society as they are capable of bringing national development through creation of goods and services, reliable sources of income, reduction of poverty and job creation. Meanwhile, one of the persistent problems militating against excellent performance of SMEs in Nigeria is a difficulty in accessing finances from formal financial institutions, because these enterprises lack substantial assets that could be utilized as collaterals for their loans. It is on this basis the Central Bank of Nigeria in 2001 attempted to provide a lasting solution to the problems of SMEs financing by making it compulsory for banks to set aside $10 \%$ of their gross profit to the financing and advancement of SMEs in Nigeria. In the same vein, further efforts to break the bottlenecks confronting SMEs financing in the country led to the emergence of microfinance bank in 2007.

However, corona virus otherwise known as COVID-19 has left indelible marks on both human beings and businesses globally. When the virus emerged in Wuhan, China in late 2019, it was viewed as China`s problem. Nobody ever envisioned that the novel COVID-19 could spread and result into global pandemic within few months. Meanwhile, fast spreading of COVID-19 without hindrance informed restrictions of non-essential travelling, goods and services among the nations, consequently resulted into the global lockdown of the world economy (WHO, 2020). The aftermath effects of COVID-19 on various socio-economic activities would not be far different from global financial crisis of 2008, which left no economy unaffected. In Nigeria like other countries, the novel virus led to various restrictions to movement of people, supply chain of goods and services, which in turn metamorphosed to the closure of non-essential factories and dwindle in production. It is important to stress that the closure of enterprises would definitely spell doom for aggregate demand and supply in which its negative ripple effects are likely to make generation of income difficult for SMEs in the country.

Consequently, in this critical period of pandemic, investigating the roles of micro financing in providing financial escape routes for SMEs is highly essential. Micro financing is supposed to create the conducive climate for the intermediation of fund from the surplus sides of the economy to the deficits parts. Nevertheless, past empirical studies have shown that SMEs in Nigeria have not fully accessed funding and essential financial services in the country (Van Rooyen, Stewart,

\& De Wet, 2012; Agbaeze \& Onwuka, 2014; Suberu, Aremu, \& Popoola, 2011, Oluseye (2014), kolawole (2013), and Lloyd and Robbins (2014). Against this backdrop, study that involves assessment of micro financing and SMEs performance becomes highly imperative in Nigeria. As a departure from the existing studies, this study examines the nexus between micro financing and SMEs development in Sango-Ota by answering the following research questions; how has micro financing impacted SMEs development in Sango- Ota, Ogun State? It is important to stress that the arrangement of this work is done as follows; the foundation of the study is laid in the introduction, while review of literature is presented in section two, section three addresses 
methodology, discussion of results and policy implication of the study respectively.

\section{Literature Review}

The emergence of novel corona virus has changed the dynamic of research in recent times. As the virus is ravaging the global economy on daily basis, efforts are being made on daily basis to flatten COVID-19 curve in various countries of the world. Generally, scholars in the field of social sciences are continuously bring out empirical evidence to substantiate the impact of COVID 19 on economy. In a study carried out by Aderemi et al. (2020), it was asserted that corona virus (COVID-19) spread to the African continent as negative side of globalization. In another study in Nigeria, Ozili \& Arun (2020) argued that corona virus pandemic led to the dwindling of the Nigerian economy and thereafter caused economic hardship on the citizens of the country. While examining the nexus between Coronavirus (COVID-19) and small and medium enterprises (SMEs) in Pakistan, Ganale and Zafar (2020) posited that corona virus pandemic affected the operating activities of the firms in a negative manner and the same time caused a disequilibrium in supply chain and financial crisis in the selected enterprises. Meanwhile, in China, Europe and USA, Collins (2020) investigated how COVID-19 pandemic affected how stock market value behaved in those economies with the aid of a differential analysis modelling. It was discovered from the paper that dynamics in stocks markets were experienced in those economies due to COVID-19 pandemic. However, a similar study was carried out in Nigeria by Aderemi et al. (2020:2) who evaluated the contribution of corona virus pandemic to small and medium enterprises in the country. It was argued in the study that a moderate fall in production and sales of SMEs and the same time a sharp in fall of contracts and deliveries were motivated by COVID-19 lockdown in the country.

\subsection{Relationship between Microfinance Bank, other Financial Intuitions and SMEs}

Oshiobugie and Ozoro (2015) employed a set of well-structured questionnaire to collect data in a study focusing on South-South, Nigeria with a view to estimating a relationship between banks, other financial institutions and entrepreneurial development. The results of the study posited that a significant direct relationship existed banks, other financial institutions and promotion of entrepreneurship development in South-South region of Nigeria. Usman, Isah and Tanko (2018) used a conceptual review to analyze various policies embarked upon by the Nigerian government in achieving Equity Investment of the Small and Medium Enterprises in the country. The author submitted that Small and medium enterprises equity investment scheme (SMEEIS) had the capacity to provide a mechanism for the growth of the Nigerian economy if appropriately managed. Franca (2013) utilized chi-square test to investigate the relationship between credits from micro institutions and SMEs development in Anambra State. The study extracted data from 450 respondents with the conclusion that a significant linkage existed between credits from micro institutions and development of SMEs in the state under investigation. While carrying out a similar study in Lagos, Ashamu (2014) used a well-structured set of 110 questionnaire and application of descriptive statistics to investigate the nexus between SMEs performance and microfinance institutions in the state. The study discovered that within 3 years of operations of microfinance institutions in the state, the institution grew phenomenally owing to expansion of the activities of informal sector in the state. Also, it was discovered from the study that the reluctance of formal financial institutions in funding the emerging micro enterprises in one hand and the metamorphosis of the community banks to microfinance banks on the other hand were the principal factors driving the operations of micro financing in the state. 
In the same vein, Ahmed (2015) investigated microfinance institutions and their challenges in combating poverty in Mogadishu, Somalia. The author employed the results from the survey to argue that a microfinance institutions had a direct impact on poverty alleviation in the country. In another perspective, Olusanya, Sufian, and Temi (2014) sourced data from 100 respondents with the application of well-structured set of questionnaire to examine how microfinance bank impacted SMEs in one hand and how microfinance policy affected employment opportunities on the other hand in Nigeria. The authors utilized a Spearman correlation to conclude that microfinance bank and SMEs growth had a positive relationship. Meanwhile, microfinance policy had a significant impact on employment opportunities in Nigeria. In the same vein, Taiwo, Yewande, Edwin, and Benson (2016) researched the contributions of microfinance institutions in funding small businesses in Lagos state. The study made use of primary data from 15 small businesses across the state to submit that the contributions of micro-financing in promoting businesses was significant and thereby reduced the resource gap for small enterprises. In a related study, Okibo and Makanga (2014) adopted descriptive survey design and stratified sampling technique to evaluate the impact of microfinance institutions on reduction of poverty in Kenya. The authors concluded that microfinance institution rendered micro financing services such as granting of small loans to various women in helping them to start and grow businesses and at the same time educating their kids.

In conclusion, studies regarding the impact of micro financing on SMEs development have received attention of scholars in different parts of Nigeria. Therefore, extending this study to Sango-Ota, the industrial area of Ogun State in this critical period of pandemic is a major contribution to the literature. Hence, the relevance of this study.

\section{Methodology and Data}

\subsection{Study Design}

This study involved the use of data from primary sources focusing on Sango-Ota industrial sub-hub of Ogun State. Few of the reasons why this location was chosen for the study are as follows; Sango Ota and its environs is characterized with the largest number of SMEs in Ogun State, Nigeria. In the same vein, Ogun State was among the three states that first went on total locked down in Nigeria because of COVID-19 pandemic.

\subsection{The Study Area}

"Sango-Ota is veritable industrial city in Ogun State, Nigeria, with an estimated population of 163,783 in the last 2006 census. Sango-Ota is the capital of the Ado-Odo Ota Local Government Area. The Local Government has the largest number of industries in the state. The local government contributes the highest internally generated revenues in Ogun state. Sango-Ota has one of the largest concentration of industries in Nigeria. " (Aderemi et al., 2020:2, P.254).

\subsection{Analytical Method}

In addressing the objectives of this study, impact of microfinance bank was measured by the volume of credit disbursed to SMEs while, SMEs development was measured by volume of trade engaged by these enterprises and profitability. Other important variables that study factored in are as follows; ownership structure of the enterprise, sectoral distribution and annual sales turnover. In the same vein, 100 SMEs who are active customers of microfinance banks and at the same time engaging in essential goods and services were purposively selected for the study. 


\section{Analysis and Presentation of Data}

\subsection{Section 1: Background Information about the Surveyed SMEs}

Table 1: Classification of Respondents by Sector/Business

\begin{tabular}{|l|l|l|l|l|}
\hline Sector/Business & Frequency & Percentage (\%) & Valid \% & Cumulative \% \\
\hline Food and Consumables & 63 & 63 & 63 & 63 \\
Oil and Gas & 21 & 21 & 21 & 84 \\
Pharmaceuticals & 16 & 16 & 16 & 100 \\
Total & 100 & 100.0 & 100.0 & \\
& & & & \\
& & & & \\
\hline
\end{tabular}

Source: Field Work (2020)

In table 1 , it has been shown that $63 \%$ of the SMEs are engaging in food and consumables, $21 \%$ of the selected business are involved in oil and gas and $16 \%$ pharmaceuticals related enterprise. The implication of this is that the majority of the participants in this study engaged in food and consumables which is one the strongest basic necessities of life.

Table 2: Ownership Structure of the Selected Enterprises

\begin{tabular}{|l|l|l|l|l|}
\hline Sector/Business & Frequency & Percentage (\%) & Valid \% & Cumulative \% \\
\hline Sole Proprietorship & 43 & 43 & 43 & 43 \\
Partnership & 18 & 18 & 18 & 61 \\
Private Limited & 21 & 21 & 21 & 82 \\
Company & & & & \\
Public Limited & 18 & 18 & 18 & 100 \\
Company & 100 & 100.0 & 100.0 & \\
Total & & & & \\
\hline
\end{tabular}

Source: Field Work (2020)

Table 2 shows the ownership structure of the selected SMEs as follows; $43 \%$ of the selected SMEs claimed to be sole proprietorship, $18 \%$ identified as partnership, $21 \%$ identified as private limited company and $18 \%$ submitted as public limited company. This shows that the majority of the respondents are one man enterprises.

Table 3: Classification of Enterprises (Annual Sales Turnover)

\begin{tabular}{|l|l|l|l|l|}
\hline $\begin{array}{l}\text { Annual Sales Turnover } \\
\text { (Naira) }\end{array}$ & Frequency & Percentage (\%) & Valid \% & Cumulative \% \\
\hline 1 million & 19 & 19 & 19 & 19 \\
2 million & 14 & 14 & 14 & 33 \\
$3-5$ million & 36 & 36 & 36 & 69 \\
6-10 million & 25 & 25 & 25 & 94 \\
11 million and above & 6 & 6 & 6 & 100 \\
Total & 100 & 100 & 100 & \\
\hline
\end{tabular}


Source: Field Work (2020)

In recognizing the financial strength of each of the selected SMEs, the study examined the annual sales turnover of the enterprises and reported as follows; $19 \%$ of the enterprises have annual turnover of 1 million naira, while 14\% have annual turnover of 2 million naira. In the same vein, $36 \%$ and $25 \%$ of the selected SMEs have 3-5 million naira and 6-10 million naira turn over respectively. But $6 \%$ has 11 million naira and above annual turnover. This implies that the majority of the selected SMEs has a minimum of 3 million naira and maximum of 10 million naira as annual turnover.

4.2 Section B: Impact of Microfinance Bank`s Credit on SMEs Development Table 4: Make Use of Micro financing Loans during COVID-19 Lock down.

\begin{tabular}{|l|l|l|l|l|}
\hline Using Microfinance Loans & Frequency & Percentage (\%) & $\begin{array}{l}\text { Valid } \\
\%\end{array}$ & Cumulative \% \\
\hline Not at all & 8 & 8 & 8 & 8 \\
To a slight extent & 10 & 10 & 10 & 18 \\
To a moderate extent & 32 & 32 & 32 & 50 \\
To a considerable extent & 29 & 29 & 29 & 79 \\
To a great extent & 15 & 15 & 15 & 94 \\
To an extreme extent & 6 & 6 & 6 & 100 \\
Total & 100 & 100 & 100 & \\
& & & & \\
& \multicolumn{2}{|l}{} \\
\end{tabular}

Source: Field Work (2020)

The above table shows that $8 \%$ of the selected firms did not make use of microfinance credit during COVID-19 lockdown. However, $10 \%$ used microfinance credit slightly during COVID-19 lockdown, 32\% used it moderately, 29\% used it in a considerable manner, $15 \%$ used it to a larger extent and it is only $6 \%$ used it extremely. This shows that over $90 \%$ of the selected

SMEs used microfinance credit for their business during COVID-19 pandemic.

\section{Section C: Outputs of SMEs Affected by Micro Financing Credit}

Table 5: SMEs`Stocks of Goods

\begin{tabular}{|l|l|l|l|l|}
\hline $\begin{array}{l}\text { Increment in Stocks after } \\
\text { Loans }\end{array}$ & Frequency & Percentage (\%) & Valid \% & Cumulative \% \\
\hline Not at all & 3 & 3 & & \\
To a slight extent & 12 & 12 & 3 & 3 \\
To a moderate extent & 39 & 39 & 12 & 15 \\
To a considerable extent & 32 & 32 & 39 & 54 \\
To a great extent & 10 & 10 & 32 & 86 \\
To an extreme extent & 4 & 4 & 10 & 96 \\
Total & 100 & 100 & 4 & 100 \\
& & & & \\
& & & & \\
\hline
\end{tabular}


Source: Field Work (2020)

In table 5, the analysis of impact of microfinance credit on the stocks of the enterprises was presented. Consequently, $3 \%$ of the selected SMEs argued that the microfinance credit has not led to increment in their stocks. Conversely, $12 \%$ of the SMEs claimed that their stocks increased slightly due to microfinance credit. $39 \%$ claimed moderate increment, $32 \%$ submitted that their stocks increased considerably, $10 \%$ experienced a large increment and $4 \%$ enjoyed extreme increment in their stocks. This implies that micro financing credit increased stock of goods of the selected SMEs during COVID-19 lockdown.

Table 6: SMEs` Profitability

\begin{tabular}{|l|l|l|l|l|}
\hline $\begin{array}{l}\text { Increment in Profitability } \\
\text { after Loans }\end{array}$ & Frequency & $\begin{array}{l}\text { Percentage } \\
(\%)\end{array}$ & Valid \% & Cumulative \% \\
\hline Not at all & 3 & 3 & 3 & 3 \\
To a slight extent & 13 & 13 & 13 & 16 \\
To a moderate extent & 45 & 45 & 45 & 61 \\
To a considerable extent & 23 & 23 & 23 & 84 \\
To a great extent & 10 & 10 & 10 & 94 \\
To an extreme extent & 6 & 6 & 6 & 100 \\
Total & 100 & 100 & 100 & \\
& & & & \\
& & & & \\
\hline
\end{tabular}

Source: Field Work (2020)

Table 6 shows impact of microfinance credit on SMEs profitability as described below; $3 \%$ of the SMEs argued that their profitability did not increase after using microfinance credit.

On the other hand, $13 \%$ claimed slight increment in profitability, $45 \%$ claimed a moderate increment. While, $23 \%$ and $10 \%$ submitted considerable and great increment respectively. But

$6 \%$ of the SMEs reported extreme profitability increment. The implication of this is that microfinance credit brought moderate rise in profit for the larger number of the SMEs selected for the survey.

\section{Summary, Conclusion and Recommendation}

This study was carried out with a view to investigating the impact of microfinance credit on entrepreneurship development amidst COVID-19 pandemic using some selected small and medium enterprises engaging in essentials such as food and consumables, oil and gas and pharmaceuticals in Sango-Ota, Ogun state, Nigeria. Primary data were collected with the aid of well-structured set of questionnaire from 100 SMEs which was done purposively. After subjecting the collected data to a rigorous analysis, it was discovered that over $90 \%$ of enterprises under investigation used microfinance credit for their business during COVID-19 pandemic. Similarly, the study submitted that micro credit increased the stock of goods of the selected SMEs during COVID-19 lockdown and at same time credit from micro finance bank brought a moderate rise in profit for the majority of the SMEs selected for the survey.

Consequently, the important findings that originated from this study led to the following recommendations for the policy makers, financial institution and all the stakeholders engaging in SMEs in Nigeria that credit from micro finance has the capacity to facilitate the development of 
entrepreneurship through expansion of outputs and profitability of SMEs in Nigeria. And as such, the policymakers in Nigeria should create an enabling environment that will facilitate microfinance institution to provide better credit and other financial facilities to SMEs in the country.

\subsection{Limitation of the Study}

It is imperative to state that this study is restricted to Sango-Ota industrial suburb of Ogun state, Nigeria. Therefore, the limitation of this study to only this area was largely due to lack of funding. Hence, its generalization is limited. However, for the purpose of increasing and improving the generalization of this study in Nigeria and Africa by extension, the authors could carry out further empirical studies in all Local Government Councils of Ogun State, all States in Nigeria or all Countries in Africa, if FUND is readily available. 


\section{References}

Aderemi, T.A., Adeniran, A. A, Amusa, B.O. \& Ebere, C. E. (2020). Globalization and Corona Virus (COVID-19) Pandemic; the Vulnerability of Africa is the Opportunity of China.Arabian Journal of Business and Management Review, 9(2), 27-30.

Aderemi, T. A., Lucas, B. O., Okoh, J. I. \& Efunbajo, S. A. (2020). Impact of Corona Virus (COVID-19) Pandemic on Small and Medium Scale Enterprises (SMEs) in Nigeria: A Critical Case Study. ACTA Universitatis Danubius, 16(4), 251-261.

Aderemi, T.A., Tolulope, A. C., Adedayo, A. \& Arinola, B. L. (2019). Entrepreneurship Financing and Nation Building in Nigeria: Evidence from Agricultural Small and Medium Scale Enterprises. Management Studies and Economic Systems, 4(4), 315- 330.

Agbaeze, E. K., \& Onwuka, I. O. (2014). Impact of microcredit on poverty alleviation in Nigeria- The case of Enugu East Local Council. International Journal of Business and Management Review, 2(1), 27-51.

Ahmed, M. D. (2015). The challenges facing microfinance institutions in poverty eradication: A case study in Mogadishu. International Journal of Humanities Social Sciences and Education (IJHSSE), 2(2), 5662.

Ashamu, S. O. (2014). The impact of micro-finance on small scale business in Nigeria. Journal of Policy and Development Studies, 289(1849), 1-15.

Collins C. N. (2020). Effect of COVID-19 Pandemic on Global Stock Market Values: A Differential Analysis. ACTA Universitatis Danubius. 16(2), 261-275.

Franca, N. (2013). The impact of micro credit institutions on the development of small and medium enterprises in Anambra State. IOSR Journal of Business and Management, 14(5), 75-81. Ganale, M. A. \& Zafar, F. (2020). Impact of COVID-19 (Coronavirus) on Small and Medium Enterprises (SMEs) in Pakistan. Small and Medium Enterprises Development Authority (SMEDA). SMEDA Research Journal View project.

Kolawole, S. (2013). Role of microfinance in Nigeria economy. Retrieved from www.preshstore.com.

Lloyd, E. J., \& Robbins, I. (2014). National microfinance policy and credit accessibility by micro, small and medium entrepreneurs in Nigeria. Journal of Good Governance and Sustainable Development in Africa (JGGSDA), 2(2), 18-30.NBS (2015). Presentation of Labour Statistics Based on Revised Concepts and Methodology for Computing Labour Statistics in Nigeria. Available at www.nigerianstat.gov.ng/pages/download/285 (accessed on 20 October 2015). Okibo, B. W., \& Makanga, N. (2014). Effects of micro finance institutions on poverty reduction in Kenya. International Journal of Current Research and Academic Review, 2(2), 76-95.

Okoh, J. I. (2020). Boosting the Nigerian Economy through Small and Medium Scale Enterprises`Financing. KIU Journal of Social Sciences, 6(3), 343-353.

Olusanya, S. O., Sufian, B. J., \& Temi, O. A. (2014). Can microfinancing improve small and medium scale enterprises in Lagos State, Nigeria? IOSR Journal of Economics and Finance (IOSR-JEF), 3(3), 49-56.

Oluseye, Y. O. (2014). Microfinance in broader perspectives (2nd ed.). Belgium: Grawhill press limited.

Ozili, P \& Arun, T. (2020). Spillover of COVID-19: Impact on the global economy.Retrieved from https://mpra.ub.uni-muenchen.de/99850/Suberu, O. J., Aremu, O. S., \& Popoola, E. G. (2011). The impact of microfinance institutions on the development of small scale enterprises in Nigeria. Journal of Research in International Business Management, 1(8), 251-257. 
Taiwo, J. N., Yewande, O. A., Edwin, A. M., \& Benson, K. N. (2016). The role of microfinance institutions in financing small businesses. Journal of Internet Banking and Commerce, 21(1), 120.

Tehseen, S. and Ramayah, T. (2015). Entrepreneurial Competencies and SMEs Business Success: The Contingent Role of External Integration. Mediterranean Journal of Social Sciences, 6(1), 50-61.

Usman, H., Isah S. \&Tanko, A. I. (2018). The Role Financial Institutions in Financing Small and Medium Enterprises in Nigeria. IIARD International Journal of Economics and Business Management, 4(4), 82-90.

Van Rooyen, C., Stewart, R., \& De Wet, T. (2012). The impact of microfinance in sub-Saharan Africa: A systematic review of the evidence. World Development, 40(11), 2249-2262. 